services. Amplifying the White Paper (see p. 71 of this issue), Mr. Marples, who doubted whether there had been purposeful direction of science and shrewd timing of applied science in the past, explained how in 1958 the saving of $£ 2$ million would be achieved in wages as well as at least $f 10$ million-worth of equipment which would have been scrapped under the old system. To secure the maximum use of the $£ 150$ million-worth of buried wires, which is increasing at the rate of $£ 11$ million a year, the Post Office is trying to bring the automatic line concentrator into operation as fast as possible, and in 1960 it is hoped to have the first all-electronic exchange in operation at Highgate Woods, as a result of the work of the Joint Electronic Research Group, a partnership between the Post Office and private enterprise. By putting in extre repeaters every three miles, it will be possible to make much better use of the existing cosxial cables, either doubling the number of conversations or providing a television channel.

Dealing with the postal services, Mr. Marples said that the procedure in sorting is essentially the same as that used one hundred years ago ; of the total cost of the postal services of $£ 120$ million, man-power accounts for 70 per cent. Of that total, sorting accounts for $£ \mathbf{4 0}$ million and delivery for $£ 30$ million. The first electronic sorting machine is already in operation at Southampton, and another, the first of a further twenty, should soon be available at Norwich. This development, which is well in advance of the rest of the world, is due to the scientists at Dollis Hill Research Station. It requires for its application a standard envelope, and Mr. Marples emphasized the importance not only of co-operation, particularly with the United States and Canada, in research, but also of public opinion. He said he is starting a scientific survey to find out what the public expect and want from the postal services and how far they are prepared to co-operate, for example, by using a code number for the address. Mentioning the International Committee of Postal Studies, Mr. Marples said that as a result of a visit by the Deputy Postmaster-General of the United States last summer, a team of five Post Office officials has studied mech. anization in Canada and in the United States. He had also appointed a committee, with Sir Leonard Sinclair as chairman, "to advise the PostmasterGeneral on the future place of the inland public telegraph services as part of the communication facilities of the United Kingdom", and he was seeking to encourage co-operation with private industry particularly in telecommunications. Help was being given by the Council for Industrial Design in standardization of telephone exchange equipment and telephone kiosks. Referring to the human problems of automation, after a tribute to the co-operation of the trade unions, Mr. Marples said that he had appointed the general secretary of the Union of Post Office Workers and the chairman of the staff side of the Post Office non-engineering Whitley Committee to the policy committee advising him on mechanization.

In replying to a question in the debate about cable-ships, the Assistant Postmaster-General, Mr. $K$. Thompson, said that the new two-way Atlantic cable to be laid in a fow years, as a result of an agreement with Canada, would be a new plasticcovered cable developed by Post Office engineers and the cable company. British two-way rigid repeaters would provide sixty conversation channels in the single cable, compared with thirty-six in the present double cable.

\section{MEDICAL USES OF IONIZING RADIATIONS}

GOLLOWING on the publication of the British and American documents setting out the Hazards to Man of Nuclear Energy, the United Nations Organization set up a Scientific Committeo on the Effects of Atomic Radiation. This Committee invited the International Commission on Radiological Protection and the International Commission on Units and Measurements to consider how best to arrive at reliable data for estimating the doses received by different parts of the human body-by individuals, and in the aggregate by large population groups-due to medical use of ionizing radiation. A study group, under the joint chairmanship of Prof. Rolf Sievert and Dr. Lauriston Taylor (chsirmen, respectively, of the two International Commissions), decided to spread the work as widely as possible. It was divided among five groups of experts drawn from fourteen countries-Austria, Cansda, Columbia, Czechoslovakia, Denmark, France, Germany, Italy, Norway, Sweden, Switzerland, the United Kingdom, the United States of America, and Uruguay.

The genetic hazard is of primary importance, and the data when accumulated will be used for assessing the significant dose per annum to the gonads of any population. A study group of the World Health Organization, which reported earlier this year, considered the possibility of registering systematically doses received by all individuals, but this proposal proved to be unrealistic. There would be too great a margin of error, and too great an expenditure of man-power and of money. There would be difficult legal and psychologicel consequences. There are, however, certain classes of persons, and certain routine procedures, for which, by a widespreed expert sampling survey, sufficiently accurate records can be obteined. The undertaking is by no mesns a light one. The data available from half a dozen countries, now publishod in Physics in Medicine and Biology, 2, No. 2 (1957), in some eighteen tables, prove to be difficult of collation; they disclose wide differences of estimated gonad dose. In Denmark and the United Kingdom it is given as about 25 mrad., in Sweden 40 mrad. and in the United States something nearer $100 \mathrm{mrad}$.

The group recommends an extensive survey, preceded by a pilot preliminary survey. It sets out the desiderats for obtaining uniformly reported information from various countries. These include classifications of age groups, the anatomical type of examination, the radiological type, and the gonad dose per examination for male, female and foetus. In estimating the dose from the internal use of radionuclides, a factor should be introduced for 'parenthood expectation' for the average patient. It is of interest that, as had boen found with other surveys, even the pertial investigation so far carried out in Great Britain has already led to a reduction of the gonad dose by adoption of the recommenda. tions included in the last report of the International Commission on Radiological Protection, and the evidence from expert measurement of the actual doses delivered. The means recommended to this end include protective devices for the gonads, a minimum film-focus distance, increased tube-housing protection, permanent filters of at least $2 \mathrm{~mm}$. aluminium equivalent on all diagnostic tubes, the use of higher-voltage techniques, exposure counters 
on all diagnostic equipment, and the use of image intensifiers.

Since the dose from diagnostic exposure outweighs that from all the other man-made sources, including that from fall-out, it is of great importance that it should be reduced by every means that does not at the same time minimize the great benefits that accrue. Radiotherapeutic dosage is of relatively far less significance.

It is recommended that basic studies should be continued; that in all countries where analysis of film records reveals a dose of more than a few per cent of natural background a detailed anslysis should be made ; that the sampling programme set out should be followed, after a pre-survey; that the team making the survey should be carefully trained, and make use only of approved dosimeters. Improved practice is confidently anticipated, and as indicated in the tables of Ardran and Crooks, should attain very considerable diminution of dose.

Prof. F. W. Spiers reports on the preliminary survey made in the United Kingdom, which expects to cover at least 5,000 examinations based on some 20,000 exposures, in three classes of hospital, and some clinics. Details of the instrumentation are given, together with forms for recording data so that transfer to punch cards is easy.

\section{Ernest Rock Caring}

\section{GIANT MOLECULES}

$I^{1}$

T seems only yesterday that a professor of physical 1 chemistry told me that a manufacturer had rung him up to ask, "What is this substance 'high poly. mers' we hear so much about? Can I make tubes of it ?" Yet to-day it would be more to the point to ask what cannot be made of it. As for the question what Nature has made of it, answers of everincreasing wonder and beauty pour out so fast that it is hard work giving them a fraction of the attention that is their due.

Our thoughts just now are much preoccupied, and excusably so, with those problems of atomic energy which betoken such a revolution in what has made up life hitherto that our future has become impossible to assess. All the same, it can be argued that in the long run, if there is going to be a long run, this is a more superficial view of things, because what is scarcely being noticed in the excitement is the quieter but far more pregnant revolution takking place simultaneously in our understanding of the molecular basis of life. Physico-chemically spesking, life is predominantly a question of the activities of chainmolecules in one form or another, and the science of man-made fibres, plastics, rubbers, and related products is an extrapolation therefrom-the lessons of Nature exemplified in a simpler but nevertheless very gretifying piece of 'homework'. The exploration of both these worlds, the old and the new, is now opening up so rapidly and excitingly that a reminder and synthesis such as that recently provided by Scientific American (197, No. 3 ; September 1957) in an issue devoted to high-polymer chemistry has a timely helpfulness that makes it doubly welcome. It comprises a set of nine articles by some of the acknowledged authorities in macromolecular studies, and they summarize an enthralling story most effectively.

The first five articles are chiefly about synthetic high polymers, and the other four are about macro- molecules in biological structures. Mark starts off with a historical survey entitled "Giant Molecules", followed by Debye on "How Giant Molecules are Measured", Natta on "How Giant Molecules are Made", Tobolsky on "The Mechanical Properties of Polymers", and Oster on "Polyethylene"-the simplest chain-molecule of its kind, but extraordinarily versatile and fast becoming the commonest. Preston writes next on "Cellulose", Doty on "Proteins", Crick on "Nucleic Acids", and finally Schmitt on "Giant Molecules in Cells and Tissues". The level of presentation is uneven, with the elementary concept often explained at lengths which some readers might prefer devoted to more advanced parts, which are as a result rather glossed over. Some non-uniformity is almost unavoidable in articles of this sort, semipopular and aimed at informing and interesting as wide a range of reader as possible. Taken together, these articles must certainly succed in doing that: there is something for everybody, from the beginner to the specialist. The illustrations are particularly fine for teaching purposes, and there is a very useful bibliography.

Among the biological contributions which I, personally, found most enjoyable, was that by Doty, in which he tells of recent progress, by measurements of light scattering and optical rotaticn, in detecting the states of folding of synthetic polypeptides and proteins in solution. The former can change over, reversibly, from right-handed $\alpha$-helices to randomly coiled chains, depending on $p H$ and other conditions, and the transition is marked also by such characteristic changes in the optical rotation and rotatory dispersion that it is natural and seems well justified to apply the criteria to the globular proteins. The results indicate (as had already been suggested from X-ray and related studies) that such globular protein molecules as have so far been tested do indeed include $\alpha$-helices in their make-up, to extents varying from 15 per cent in ribonuclease to 85 per cent in tropomyosin; and what is more, these proportions can be varied reversibly, and when the protein is an enzyme, activity goes up and down correspondingly. By implication, the seme sort of adaptability of the intramolecular mixture of $\alpha$-helical and randomlycoiled could account for the versatility of the $\gamma$-globulins and the formation of antibodies.

The main theme of Natta's article is the astonishing advances in the controlled building of high polymers that have been made within only the past few years by means of complex ionic catalysts, following Ziegler's production, for exsmple, of unbranched polyethylene at atmospheric pressure and temperatures not much above $30^{\circ} \mathrm{C}$. Vinyl polymers now run into molecular weights of millions, with their side-groups arranged at will in a so-called 'atactic', 'isotactic' or 'syndiotactic' sequence according as they occur at random on either side, all on the same side, or regularly distributed from side to side. Truly, as Natta says, "we can hardly begin to conceive how profoundly this new chemistry will affect man's life".

All this though, impressive as it is, is still child's play compared with the kind of thing discussed by Crick in his article on the nucleic acids. Deoxyribonucleic acid and ribonucleic acid have lately come to be recognized as the 'master race' of biological high polymers, in that apparently they alone can both transmit messages of heredity and afterwards dominate the business of protein synthesis. Recent 